\title{
Structural differences between deuterated and hydrogenated silicon nitride/oxynitride
}

\author{
An Shih, Shin-Hung Yeh, and Si-Chen Lee ${ }^{a)}$ \\ Department of Electrical Engineering, National Taiwan University, Taipei, Taiwan, Republic of China \\ T. R. Yang \\ Department of Physics, National Normal University, Taipei, Taiwan, Republic of China
}

(Received 9 October 2000; accepted for publication 16 February 2001)

\begin{abstract}
Hydrogenated and deuterated silicon nitride $\left(a-\mathrm{SiN}_{x}: \mathrm{H}\right.$ and $\left.a-\mathrm{SiN}_{x}: \mathrm{D}\right)$ and silicon oxynitride $\left(a-\mathrm{SiO}_{x} \mathrm{~N}_{y}: \mathrm{H}\right.$ and $\left.a-\mathrm{SiO}_{x} \mathrm{~N}_{y}: \mathrm{D}\right)$ films are prepared by plasma-enhanced chemical vapor deposition. Their transmission and photoluminescence spectra were measured. Both the photoluminescence and transmission spectra show that the deuterated films have higher energy gaps than those of the hydrogenated films in the same growth condition. The infrared absorption spectra of these samples are identified and compared in detail. From the infrared spectra, the interaction between $\mathrm{N}-\mathrm{D}$ bond rocking vibration and $\mathrm{Si}-\mathrm{N}$ bond stretching vibration is observed, which pushes $\mathrm{N}-\mathrm{D}$ bond rocking vibration to a higher energy. It is also observed that the refractive index of deuterated film is lower than the hydrogenated film in the same growth condition due to its lower density. (C) 2001 American Institute of Physics. [DOI: 10.1063/1.1364645]
\end{abstract}

\section{INTRODUCTION}

Recently, the hot electron degradation in silicon metal oxide semiconductor field effect transistor (MOSFET) has been found to be greatly reduced by passivating the siliconsilicon dioxide interface using deuterium instead of hydrogen ${ }^{1}$ and several articles ${ }^{2-5}$ also demonstrate that the incorporation of deuterium instead of hydrogen in amorphous silicon tends to slow the decay of its photoconductivity under illumination and improves the reliability of thin film transistor. ${ }^{6}$ It encourages us to study the effect when deuterium atoms are incorporated into the insulator such as silicon nitride and silicon oxynitride. Silicon nitride and silicon oxide are the most popular insulators in the microelectronic device technology. They are widely used for many applications, such as surface passivation, interlayer insulator, diffusion mask, and gate insulator. Plasma-enhanced chemical vapor deposition (PECVD) is usually used to deposit silicon nitride. However, when $\mathrm{N}_{2} \mathrm{O}$ gas is used in PECVD to prepare silicon dioxide, the grown films contain nitrogen atoms and become silicon oxynitride films. Hydrogenated and deuterated silicon nitride $\left(a-\mathrm{SiN}_{x}: \mathrm{H}\right.$ and $\left.a-\mathrm{SiN}_{x}: \mathrm{D}\right)$ and silicon oxynitride $\left(a-\mathrm{SiO}_{x} \mathrm{~N}_{y}: \mathrm{H}\right.$ and $\left.a-\mathrm{SiO}_{x} \mathrm{~N}_{y}: \mathrm{D}\right)$ films were prepared by PECVD. Their Fourier transform infrared (FTIR) spectra, photoluminescence (PL) spectra, transmission spectra, growth rates, and refractive indexes were measured and studied in detail in this article.

\section{EXPERIMENT}

Hydrogenated and deuterated silicon nitride $\left(a-\mathrm{SiN}_{x}: \mathrm{H}\right.$ and $\left.a-\mathrm{SiN}_{x}: \mathrm{D}\right)$ and silicon oxynitride $\left(a-\mathrm{SiO}_{x} \mathrm{~N}_{y}: \mathrm{H}\right.$ and $\left.a-\mathrm{SiO}_{x} \mathrm{~N}_{y}: \mathrm{D}\right)$ films were deposited on high-resistivity (30 $\Omega \mathrm{cm}$ ) two-sided polished (100) crystalline silicon by

${ }^{a)}$ Electronic mail: sclee@cc.ee.ntu.edu.tw
PECVD. The reason for using two-sided polished substrates is because unpolished substrates tend to strongly scatter the IR light in the wavelength range 2-10 $\mu \mathrm{m}$. The deposition parameters were as follows: rf power density is $0.26 \mathrm{~W} / \mathrm{cm}^{2}$, the substrate temperature $250^{\circ} \mathrm{C}$, the electrode space $3 \mathrm{~cm}$, and chamber pressure 0.45 Torr. The gas flow rates and growth rates of eight samples are listed in Table I. The gas phase composition $\mathrm{Xg}$ is defined as $\mathrm{ND}_{3} /\left(\mathrm{SiD}_{4}+\mathrm{ND}_{3}\right)$ or $\mathrm{NH}_{3} /\left(\mathrm{SiH}_{4}+\mathrm{NH}_{3}\right)$ in the silicon nitride materials and as $\mathrm{N}_{2} \mathrm{O} /\left(\mathrm{SiD}_{4}+\mathrm{N}_{2} \mathrm{O}\right)$ or $\mathrm{N}_{2} \mathrm{O} /\left(\mathrm{SiH}_{4}+\mathrm{N}_{2} \mathrm{O}\right)$ in the silicon oxynitride materials. To identify the IR absorption peaks of hydrogenated and deuterated silicon nitride and silicon oxynitride films, these samples were prepared in high dilution and low dilution conditions, respectively. In order to identify which radical group gave rise to the observed peak, the samples were annealed at the temperature from 300 to $800^{\circ} \mathrm{C}$ for 10 min in each step. The refractive index and growth rate were measured by ellipsometry which utilized a $\mathrm{He}-\mathrm{Ne}$ laser $(\lambda$ $=632.8 \mathrm{~nm}$ ) as the light source. Because the thickness of the samples might alter the escaping rates of hydrogen and deuterium atoms, the thicknesses of silicon nitride samples with $\mathrm{Xg}=0.95$ are kept the same, $100 \mathrm{~nm}$ thick; the silicon nitride samples with $\mathrm{Xg}=0.5$ and silicon oxynitride samples with $\mathrm{Xg}=0.6$ are kept the same, $200 \mathrm{~nm}$ thick; and the silicon oxynitride samples with $\mathrm{Xg}=0.15$ are kept the same, $80 \mathrm{~nm}$ thick. The SIMS data were used to determine the concentration of hydrogen atoms, measured by Cameca $5 f$ in ultrahigh vacuum. The hydrogen standard sample was purchased from Charles Evans Standard, which was prepared by ion implanting known quantity of hydrogen atoms into the $c$-Si substrate. The FTIR spectra were measured by Bruker IFS 120 HR IR spectrometer. The resolution of the infrared spectra was $0.48 \mathrm{~cm}^{-1}$. Since the IR spectra of $\mathrm{Si}-\mathrm{D}$ stretching mode was mixed with the absorption of water vapor in air, the infrared spectra of all samples were measured at room 
TABLE I. Gas flow rates, growth rates, and refractive indexes of hydrogenated and deuterated silicon nitride $\left(a-\mathrm{SiN}_{x}: \mathrm{H}\right.$ and $\left.a-\mathrm{SiN}_{x}: \mathrm{D}\right)$ and silicon oxynitride $\left(a-\mathrm{SiO}_{x} \mathrm{~N}_{y}: \mathrm{H}\right.$ and $\left.a-\mathrm{SiO}_{x} \mathrm{~N}_{y}: \mathrm{D}\right)$ films.

\begin{tabular}{clllcl}
\hline \hline $\begin{array}{c}\text { Sample } \\
\text { No. }\end{array}$ & \multicolumn{1}{c}{ Material } & \multicolumn{1}{c}{$\mathrm{Xg}$} & \multicolumn{1}{c}{$\begin{array}{c}\text { Gas flow rate } \\
(\mathrm{sccm})\end{array}$} & $\begin{array}{c}\text { Growth rate } \\
(\mathrm{nm} / \mathrm{min})\end{array}$ & $\begin{array}{c}\text { Refractive } \\
\text { index }\end{array}$ \\
\hline 1 & $a-\mathrm{SiN}_{x}: \mathrm{D}$ & 0.95 & $\mathrm{SiD}_{4}: \mathrm{ND}_{3}=1: 19$ & 9.6 & 1.714 \\
2 & $a-\mathrm{SiN}_{x}: \mathrm{H}$ & 0.95 & $\mathrm{SiH}_{4}: \mathrm{NH}_{3}=1: 19$ & 12.8 & 1.8 \\
3 & $a-\mathrm{SiN}_{x}: \mathrm{D}$ & 0.5 & $\mathrm{SiD}_{4}: \mathrm{ND}_{3}=2: 2$ & 23.3 & 2.28 \\
4 & $a-\mathrm{SiN}_{x}: \mathrm{H}$ & 0.5 & $\mathrm{SiH}_{4}: \mathrm{NH}_{3}=2: 2$ & 19.4 & 2.74 \\
5 & $a-\mathrm{SiO}_{x} \mathrm{~N}_{y}: \mathrm{D}$ & 0.6 & $\mathrm{SiD}_{4}: \mathrm{N}_{2} \mathrm{O}: \mathrm{D}_{2}=2: 3: 5$ & 32.4 & 1.564 \\
6 & $a-\mathrm{SiO}_{x} \mathrm{~N}_{y}: \mathrm{H}$ & 0.6 & $\mathrm{SiH}_{4}: \mathrm{N}_{2} \mathrm{O}: \mathrm{H}_{2}=2: 3: 5$ & 28.6 & 1.828 \\
7 & $a-\mathrm{SiO}_{x} \mathrm{~N}_{y}: \mathrm{D}$ & 0.15 & $\mathrm{SiD}_{4}: \mathrm{N}_{2} \mathrm{O}: \mathrm{D}_{2}=2: 0.35: 5$ & 10.2 & 3.02 \\
8 & $a-\mathrm{SiO}_{x} \mathrm{~N}_{y}: \mathrm{H}$ & 0.15 & $\mathrm{SiH}_{4}: \mathrm{N}_{2} \mathrm{O}: \mathrm{H}_{2}=2: 0.35: 5$ & 9.5 & 3.31 \\
\hline \hline
\end{tabular}

temperature in high vacuum. To obtain higher resolution, the spectra were measured and averaged for 1024 times. The PL spectra were measured via excitation by an argon laser at a wavelength of $457.9 \mathrm{~nm}$ or $\mathrm{He}-\mathrm{Cd}$ laser at a wavelength of $325 \mathrm{~nm}$.

\section{RESULTS AND DISCUSSION}

The growth rates and refractive indexes measured at $632.8 \mathrm{~nm}$ of silicon nitride and oxynitride are listed in Table I. Apparently, the refractive index of deuterated material is lower than that of hydrogenated material in the same growth condition. The growth rate of $a-\mathrm{SiO}_{x} \mathrm{~N}_{y}$ :D is faster than that of $a-\mathrm{SiO}_{x} \mathrm{~N}_{y}: \mathrm{H}$. This phenomenon still exists in silicon nitride when $\mathrm{Xg}$ equals 0.5 (low dilution condition), such as samples 3 and 4 . The low dilution growth condition would suggest that a higher effective dilution is obtained for $\mathrm{SiD}_{4}$ than for $\mathrm{SiH}_{4}$, which leads to a higher electron temperature and thus a higher dissociation rate and a higher growth rate. The similar phenomenon is observed in amorphous silicon films ${ }^{7}$ but when $\mathrm{Xg}$ equals 0.95 (high dilution condition), to the contrary, the growth rate of hydrogenated silicon nitride becomes faster than that of deuterated silicon nitride, which means replacing $\mathrm{SiH}_{4}$ with $\mathrm{SiD}_{4}$ will increase the growth rate, but using $\mathrm{ND}_{3}$ instead of $\mathrm{NH}_{3}$ will slow down the growth rate.

\section{A. Optical absorption spectra}

Figures 1(a) and 1(b) display the absorption spectra, i.e., $(\alpha h \nu)^{1 / 2}$ vs $h \nu$, for the silicon nitride samples with $\mathrm{Xg}$ $=0.95$ and 0.5 , respectively. By extrapolating the linear part of the figure to the horizontal axis, the optical gap $\left(E_{\text {gopt }}\right)$ of the films can be extracted according to the empirical formula derived by Tauc; ${ }^{8}$

$$
(\alpha h \nu)^{1 / 2}=B\left(h \nu-E_{\text {gopt }}\right) .
$$

The optical gaps of deuterated and hydrogenated silicon nitride films with $\mathrm{Xg}=0.95$ are 5.13 and $4.98 \mathrm{eV}$, respectively. The optical gaps of deuterated and hydrogenated silicon nitride films with $\mathrm{Xg}=0.5$ are 2.44 and $2.23 \mathrm{eV}$, respectively. It is obvious that the deuterated silicon nitride has a higher optical gap than that of the hydrogenated one in the same growth condition. The silicon oxynitride films also exhibit the similar characteristics as show in Figs. 1(c) and 1(d). The optical gaps of deuterated and hydrogenated silicon oxyni- tride films with $\mathrm{Xg}=0.6$ are 3.18 and $2.68 \mathrm{eV}$, respectively, and with $\mathrm{Xg}=0.15$ are 2.09 and $2.01 \mathrm{eV}$, respectively.

\section{B. PL spectra}

The PL spectra of $a-\mathrm{SiN}_{x}: \mathrm{D}$ and $a-\mathrm{SiN}_{x}: \mathrm{H}$ films with $\mathrm{Xg}=0.5$ are shown in Fig. 2. The PL spectra were measured at $15 \mathrm{~K}$ via $\mathrm{He}-\mathrm{Cd}$ laser with $325 \mathrm{~nm}$ as the excitation source. Obviously, the PL peak of $a-\mathrm{SiN}_{x}$ :D film is at higher energy than that of the $a-\mathrm{SiN}_{x}: \mathrm{H}$ film in the same growth condition. Both are 0.3 to $0.5 \mathrm{eV}$ lower than their respective optical gap. Therefore, the PL band originates from recombination of carriers trapped in the band tails. The wider optical gap of $a-\mathrm{SiN}_{x}: \mathrm{D}$ makes its PL peak higher than that of $a-\mathrm{SiN}_{x}: \mathrm{H}$. Several peaks are observed in PL spectra of $a-\mathrm{SiN}_{x}: \mathrm{D}$ and $a-\mathrm{SiN}_{x}: \mathrm{H}$ films, which means that inhomogeneity and thus the different quantum confinement effect exists in these films. ${ }^{9}$ The PL spectra of $a-\mathrm{SiO}_{x} \mathrm{~N}_{y}: \mathrm{D}$ and $a-\mathrm{SiO}_{x} \mathrm{~N}_{y}: \mathrm{H}$ films with $\mathrm{Xg}=0.6$ are shown in Fig. 3. The PL spectra were measured at $15 \mathrm{~K}$ using $325 \mathrm{~nm} \mathrm{He}-\mathrm{Cd}$ laser as the excitation source. The PL peak of $a-\mathrm{SiO}_{x} \mathrm{~N}_{y}: \mathrm{D}(2.2 \mathrm{eV})$ is at a higher energy than the peak of $a-\mathrm{SiO}_{x} \mathrm{~N}_{y}: \mathrm{H}(2.08 \mathrm{eV})$ because of its higher optical energy gap as well. Figure 4 displays the PL spectra of $a-\mathrm{SiO}_{x} \mathrm{~N}_{y}: \mathrm{D}$ and $a-\mathrm{SiO}_{x} \mathrm{~N}_{y}: \mathrm{H}$ films with $\mathrm{Xg}=0.15$. The PL spectra were measured at $10 \mathrm{~K}$ using $457.9 \mathrm{~nm} \mathrm{Ar}^{+}$laser as the excitation source. Because the photoluminescence efficiency of these two samples are poorer than those of the other samples, the $\mathrm{Ar}^{+}$laser is used to replace the $\mathrm{He}-\mathrm{Cd}$ laser as the pumping source to get the better spectra. The PL peak of $a-\mathrm{SiO}_{x} \mathrm{~N}_{y}: \mathrm{D}(1.7 \mathrm{eV})$ is at higher energy than that of $a-\mathrm{SiO}_{x} \mathrm{~N}_{y}: \mathrm{H}(1.65 \mathrm{eV})$ because of its higher optical energy gap. Because the optical gaps of $a-\mathrm{SiN}_{x}: \mathrm{D}$ and $a-\mathrm{SiN}_{x}: \mathrm{H}$ films with $\mathrm{Xg}=0.95$ are too high to get the PL spectra via the $\mathrm{He}-\mathrm{Cd}$ laser as pumping source, the PL spectra of these two samples are not shown in this article.

\section{IR spectra}

Figure 5 shows the IR spectra of deuterated and hydrogenated silicon nitride with $\mathrm{Xg}=0.95$ and 0.5 , respectively. For $a-\mathrm{SiN}_{x}: \mathrm{H}$ film with $\mathrm{Xg}=0.95$, the $\mathrm{N}-\mathrm{H}$ stretching mode vibration is at $3342 \mathrm{~cm}^{-1}$. ${ }^{10}$ The small peak in $3445 \mathrm{~cm}^{-1}$ is the $\mathrm{N}-\mathrm{H}_{2}$ stretching mode vibration. For $a-\mathrm{SiN}_{x}$ :D film with $\mathrm{Xg}=0.95$, the $\mathrm{N}-\mathrm{D}$ stretching mode vibration is at 2470 $\mathrm{cm}^{-110}$ and the $\mathrm{N}-\mathrm{D}_{2}$ stretching mode vibration is 2562 


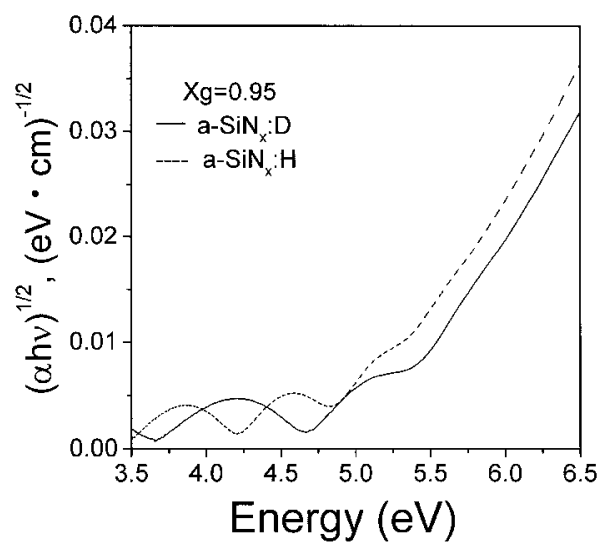

(a)

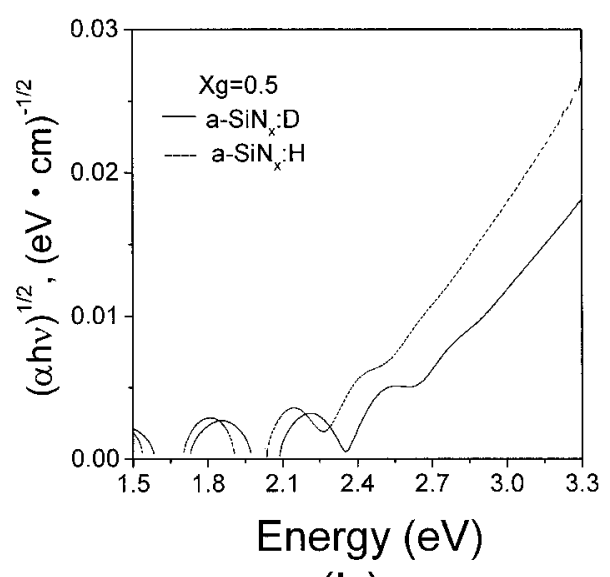

(b)

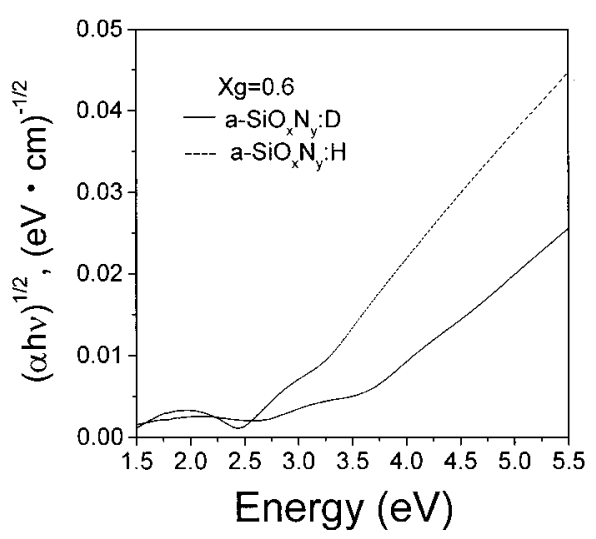

(c)

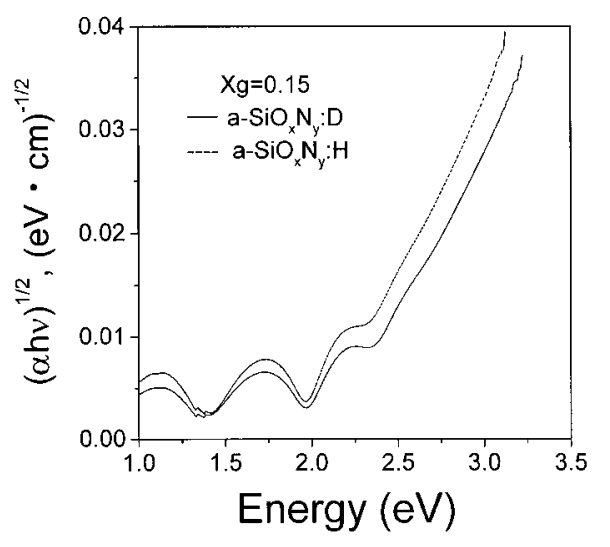

(d)
FIG. 1. $(\alpha h \nu)^{1 / 2}$ vs photon energy plot of (a) $a-\mathrm{SiN}_{x}: \mathrm{D}$ and $a-\mathrm{SiN}_{x}: \mathrm{H}$ with $\mathrm{Xg}=0.95$, (b) $a-\mathrm{SiN}_{x}: \mathrm{D}$ and $a-\mathrm{SiN}_{x}: \mathrm{H}$ with $\mathrm{Xg}=0.5$, (c) $\mathrm{SiO}_{x} \mathrm{~N}_{y}: \mathrm{D}$, and $a-\mathrm{SiO}_{x} \mathrm{~N}_{y}: \mathrm{H}$ with $\mathrm{Xg}$ $=0.6, \quad$ (d) $\quad \mathrm{SiO}_{x} \mathrm{~N}_{y}: \mathrm{D}, \quad$ and $a-\mathrm{SiO}_{x} \mathrm{~N}_{y}: \mathrm{H}$ with $\mathrm{Xg}=0.15$. The solid lines represent the spectra of the deuterated materials and the dashed lines represent the hydrogenated materials. $\mathrm{cm}^{-1}$. The ratio of $\mathrm{N}-\mathrm{H}$ stretching mode vibration frequency to $\mathrm{N}-\mathrm{D}$ stretching mode vibration frequency is 1.35 , approximately inversely proportional to the square root of the ratio of their reduced mass. The ratio of $\mathrm{N}-\mathrm{H}_{2}$ bending mode frequency to $\mathrm{N}-\mathrm{D}_{2}$ bending mode frequency is also approximately equal to 1.35 . In the $a-\mathrm{Si}: \mathrm{H}$ films, the stretching mode for $\mathrm{Si}-\mathrm{H}$ monohydride located in a small void (one silicon vacancy) is at $2000 \mathrm{~cm}^{-1}$, whereas for $\mathrm{SiH}$ monohy- dride and $\mathrm{SiH}_{2}$ dihydride located in a large void, the peak shifts to 2070-2090 $\mathrm{cm}^{-1}$. In $a-\mathrm{SiN}_{x}: \mathrm{H}$ film, the existence of nitrogen atoms back bonded to $\mathrm{SiH}_{n}$ radicals shifts the $2080 \mathrm{~cm}^{-1}$ peak to the higher frequency because of the greater electronegativity of nitrogen atom as compared to silicon atom. ${ }^{11,12}$ Therefore, in the hydrogenated silicon nitride sample with $\mathrm{Xg}=0.95$, the small peak at $2150 \mathrm{~cm}^{-1}$ is the $\mathrm{Si}-\mathrm{H}$ stretching mode vibration with nitrogen atoms back

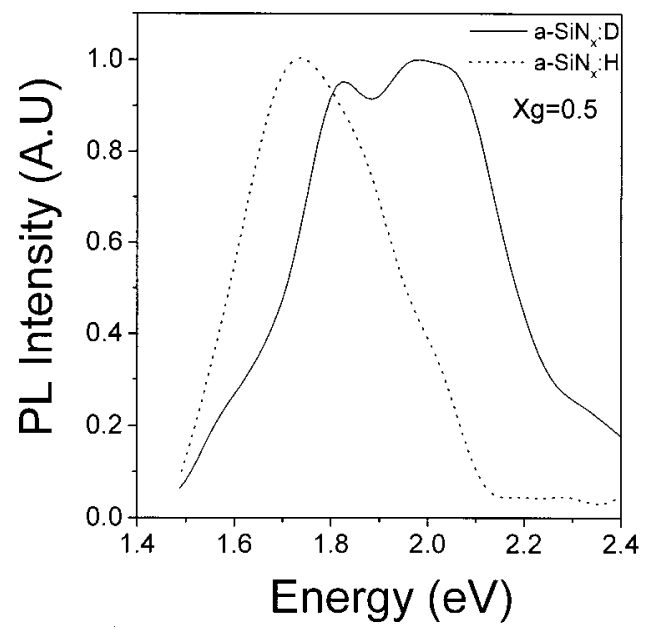

FIG. 2. $15 \mathrm{~K}$ PL spectra of $a-\mathrm{SiN}_{x}: \mathrm{D}$ and $a-\mathrm{SiN}_{x}: \mathrm{H}$ with $\mathrm{Xg}=0.5$.

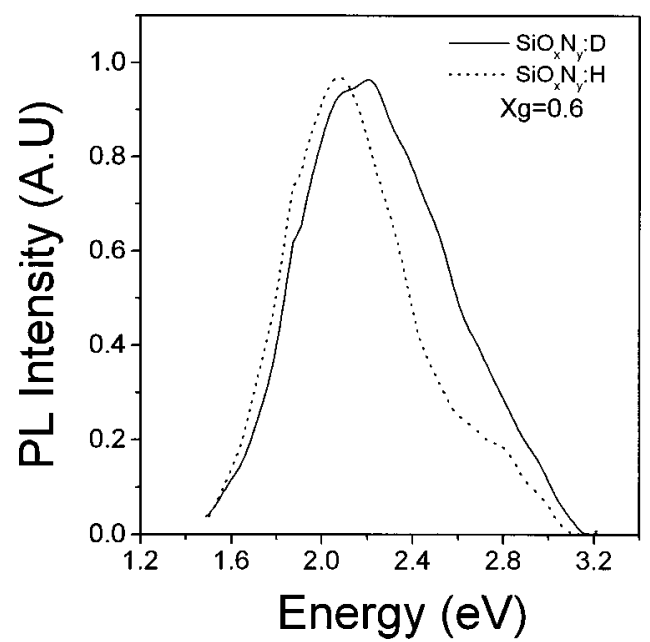

FIG. 3. $15 \mathrm{~K}$ PL spectra of $a-\mathrm{SiO}_{x} \mathrm{~N}_{y}: \mathrm{D}$ and $a-\mathrm{SiO}_{x} \mathrm{~N}_{y}: \mathrm{H}$ with $\mathrm{Xg}=0.6$. 


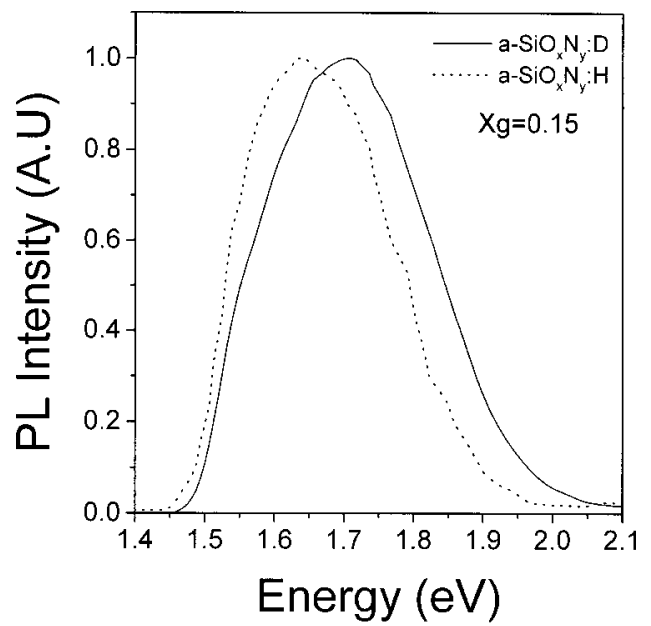

FIG. 4. $10 \mathrm{~K}$ PL spectra of $a-\mathrm{SiO}_{x} \mathrm{~N}_{y}: \mathrm{D}$ and $a-\mathrm{SiO}_{x} \mathrm{~N}_{y}: \mathrm{H}$ with $\mathrm{Xg}=0.15$.

bonded to $\mathrm{Si}-\mathrm{H}$. The $\mathrm{Si}-\mathrm{D}$ stretching mode vibration of deuterated silicon nitride sample with $\mathrm{Xg}=0.95$ is too small to be identified clearly. The concentration of $\mathrm{N}-\mathrm{H}$ bonds can be calculated by the experimentally measured FTIR spectral areas according to the relation: ${ }^{13}$

$$
\begin{aligned}
N_{\mathrm{N}-\mathrm{H}} & =\frac{c n \omega_{t}}{2 \pi^{2}} \frac{\mu}{e_{s}^{* 2}} \int \frac{\alpha(\omega)}{\omega} d \omega, \\
& =A_{\mathrm{N}-\mathrm{H}}^{s} \times \int \frac{\alpha(\omega)}{\omega} d \omega,
\end{aligned}
$$

where $c$ is the light velocity, $n$ the refractive index, $\mu$ the reduced mass of $\mathrm{N}$ and $\mathrm{H}, \omega_{t}$ the peak absorption frequency, $e_{s}^{*}$ the effective charge of the $\mathrm{N}-\mathrm{H}$ bond, and $\alpha$ the absorp-

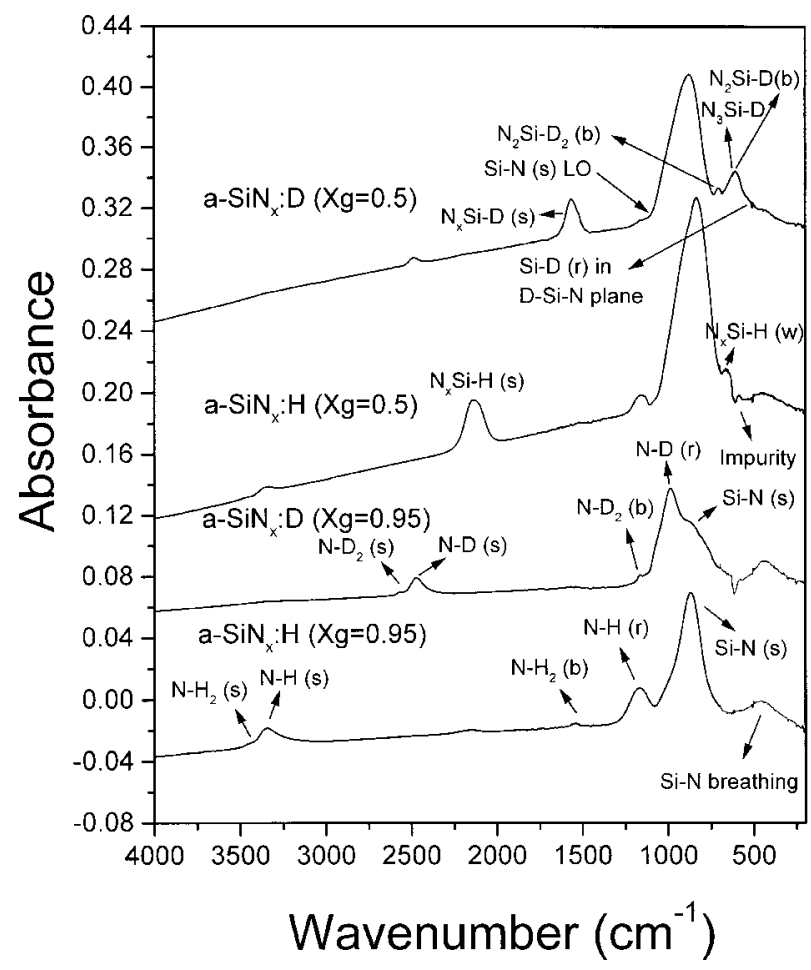

FIG. 5. IR spectra of $a-\mathrm{SiN}_{x}: \mathrm{D}$ and $a-\mathrm{SiN}_{x}: \mathrm{H}$ films with $\mathrm{Xg}=0.95$ and 0.5 .
TABLE II. Optical gaps, concentration of $\mathrm{N}-\mathrm{D}(\mathrm{H})$ bonds and concentration of $\mathrm{Si}-\mathrm{D}(\mathrm{H})$ bonds of deuterated and hydrogenated silicon nitride $\left(a-\mathrm{SiN}_{x}: \mathrm{H}\right.$ and $\left.a-\mathrm{SiN}_{x}: \mathrm{D}\right)$ and silicon oxynitride $\left(a-\mathrm{SiO}_{x} \mathrm{~N}_{y}: \mathrm{H}\right.$ and $\left.a-\mathrm{SiO}_{x} \mathrm{~N}_{y}: \mathrm{D}\right)$ films.

\begin{tabular}{cccccc}
\hline $\begin{array}{c}\text { Sample } \\
\text { No. }\end{array}$ & Material & $\mathrm{Xg}$ & $\begin{array}{c}\text { Optical gap } \\
(\mathrm{eV})\end{array}$ & $\begin{array}{c}\mathrm{N}-\mathrm{D} / \mathrm{N}-\mathrm{H} \\
\left(\mathrm{cm}^{-3}\right)\end{array}$ & $\begin{array}{c}\mathrm{Si}-\mathrm{D} / \mathrm{Si}-\mathrm{H} \\
\left(\mathrm{cm}^{-3}\right)\end{array}$ \\
\hline 1 & $a-\mathrm{SiN}_{x}: \mathrm{D}$ & 0.95 & 5.13 & $4.7 \times 10^{22}$ & \\
2 & $a-\mathrm{SiN}_{x}: \mathrm{H}$ & 0.95 & 4.98 & $2.4 \times 10^{22}$ & $8.4 \times 10^{20}$ \\
3 & $a-\mathrm{SiN}_{x}: \mathrm{D}$ & 0.5 & 2.44 & $6.5 \times 10^{21}$ & $2.1 \times 10^{22}$ \\
4 & $a-\mathrm{SiN}_{x}: \mathrm{H}$ & 0.5 & 2.23 & $2.5 \times 10^{21}$ & $1.9 \times 10^{22}$ \\
5 & $a-\mathrm{SiO}_{x} \mathrm{~N}_{y}: \mathrm{D}$ & 0.6 & 3.18 & & $5.7 \times 10^{21}$ \\
6 & $a-\mathrm{SiO}_{x} \mathrm{~N}_{y}: \mathrm{H}$ & 0.6 & 2.68 & & $1.1 \times 10^{22}$ \\
7 & $a-\mathrm{SiO}_{x} \mathrm{~N}_{y}: \mathrm{D}$ & 0.15 & 2.09 & & $1.4 \times 10^{22}$ \\
8 & $a-\mathrm{SiO}_{x} \mathrm{~N}_{y}: \mathrm{H}$ & 0.15 & 2.01 & & $1.2 \times 10^{22}$ \\
\hline \hline
\end{tabular}

tion coefficient. This relationship can also be applied to measure the $\mathrm{N}-\mathrm{D}, \mathrm{Si}-\mathrm{H}$, and $\mathrm{Si}-\mathrm{D}$ concentration. $A_{\mathrm{N}-\mathrm{H}}^{s}$ is the proportionality constant relating the integrated stretching mode absorption to the concentrations of $\mathrm{N}-\mathrm{H}$ bonds. Similarly, $A_{\mathrm{N}-\mathrm{D}}^{s}$ is the proportionality constant of N-D bonds to integrated $\mathrm{N}-\mathrm{D}$ absorption spectra. The hydrogen concentration of $a-\mathrm{SiN}_{x}: \mathrm{H}$ with $\mathrm{Xg}=0.95$ was measured by SIMS to be $2.4 \times 10^{22} \mathrm{~cm}^{-3}$ which equals the sum of $\mathrm{N}-\mathrm{H}$ bonds plus $\mathrm{Si}-\mathrm{H}$ bonds. $A_{\mathrm{Si}-\mathrm{H}}^{s}$ and $A_{\mathrm{Si}-\mathrm{D}}^{s}$ are $6.9 \times 10^{19}$ and $1 \times 10^{20}$, respectively. ${ }^{7}$ Then the averaged values for $A_{\mathrm{N}-\mathrm{H}}^{s}$ can be determined by Eq. (4), which is equal to $2.6 \times 10^{20}$. From Eq. (3), since the $\omega_{t} \mu$ value of N-D stretching mode is $\sqrt{2}$ times larger, where other parameters are the same as these values of a $\mathrm{N}-\mathrm{H}$ stretching mode vibration, $A_{\mathrm{N}-\mathrm{D}}^{s}$ should be $\sqrt{2}$ times larger than $A_{\mathrm{N}-\mathrm{H}}^{s}$, which is $3.7 \times 10^{20}$ then the concentrations of $\mathrm{N}-\mathrm{D}, \mathrm{N}-\mathrm{H}, \mathrm{Si}-\mathrm{D}$, and $\mathrm{Si}-\mathrm{H}$ bonds could be obtained by Eq. (4), which are listed in Table II. The Si-D stretching mode IR peak of $a-\mathrm{SiN}_{x}$ : $\mathrm{D}$ with $\mathrm{Xg}=0.95$ is too small to integrate accurately; therefore, the concentration of $\mathrm{Si}-\mathrm{D}$ bonds of this sample cannot be obtained.

In Fig. 5, the peaks of $a-\mathrm{SiN}_{x}: \mathrm{H}$ film with $\mathrm{Xg}=0.95$ at 1544,1170 , and $870 \mathrm{~cm}^{-1}$ are $\mathrm{N}-\mathrm{H}_{2}$ bending mode, $\mathrm{N}-\mathrm{H}$ rocking mode, and $\mathrm{Si}-\mathrm{N}$ stretching mode vibration, respectively. ${ }^{10,11}$ The peak of $a-\mathrm{SiN}_{x}$ :D film with $\mathrm{Xg}=0.95$ at $1165 \mathrm{~cm}^{-1}$ is $\mathrm{N}-\mathrm{D}_{2}$ bending mode vibration. The position of $\mathrm{N}-\mathrm{D}$ rocking mode vibration could be obtained by dividing the frequency of $\mathrm{N}-\mathrm{H}$ rocking mode vibration by $\sqrt{2}$, which is equal to $829 \mathrm{~cm}^{-1}$ but this position is close to the position of $\mathrm{Si}-\mathrm{N}$ stretching mode vibration, therefore the interaction between $\mathrm{N}-\mathrm{D}$ rocking mode and $\mathrm{Si}-\mathrm{N}$ stretching mode vibration is expected. As shown in Fig. 5, two peaks could be the candidates for the $\mathrm{N}-\mathrm{D}$ rocking mode vibration. One peak is at $987 \mathrm{~cm}^{-1}$ and the other is the shoulder at approximately $860 \mathrm{~cm}^{-1}$. However, because the peak at 987 $\mathrm{cm}^{-1}$ decreases with the rise of the annealing temperature as shown in Fig. 6(a), it should be the N-D rocking mode vibration and the shoulder at $860 \mathrm{~cm}^{-1}$ should be the $\mathrm{Si}-\mathrm{N}$ stretching mode vibration. The ratio of $\mathrm{N}-\mathrm{H}$ to $\mathrm{N}-\mathrm{D}$ stretching mode vibration frequency is 1.35 , whereas the ratio of $\mathrm{N}-\mathrm{H}$ to $\mathrm{N}-\mathrm{D}$ rocking mode vibration is only 1.19 . The reason is that the interaction between the $\mathrm{N}-\mathrm{D}$ rocking mode and $\mathrm{Si}-\mathrm{N}$ stretching mode vibrations pushes $\mathrm{N}-\mathrm{D}$ rocking mode to a higher energy.

In Fig. 6(a), when $a-\mathrm{SiN}_{x}: \mathrm{D}$ and $a-\mathrm{SiN}_{x}: \mathrm{H}$ films with 


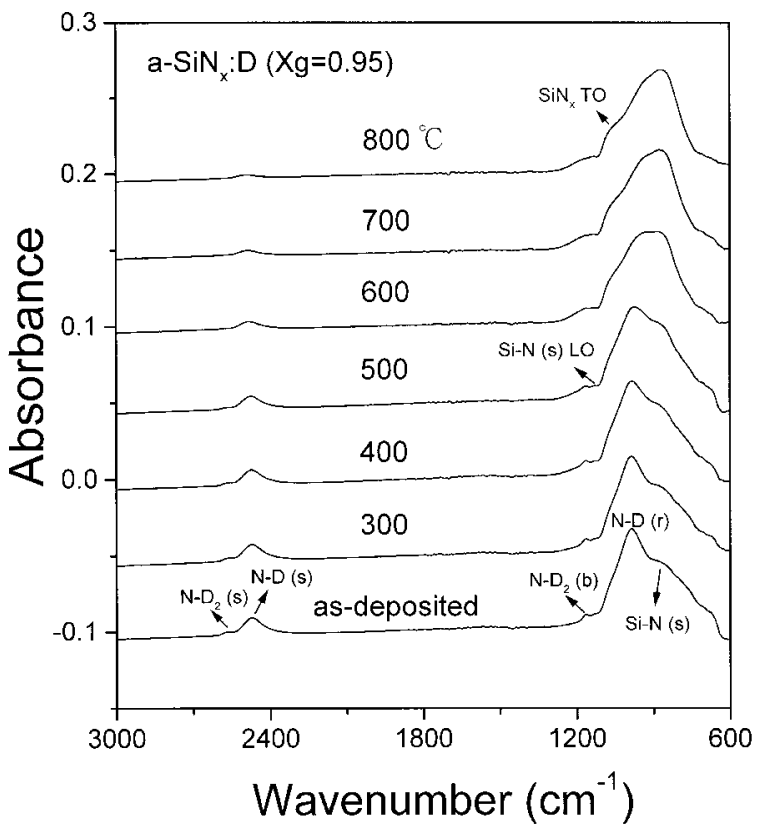

(a)

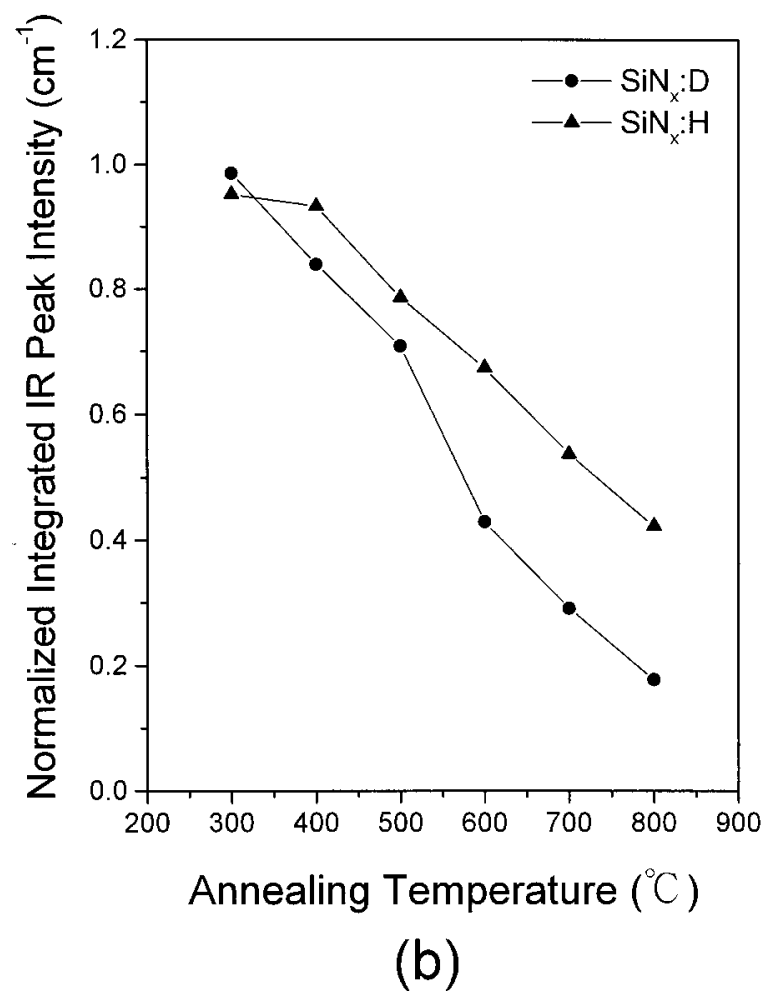

FIG. 6. IR spectra of (a) $a-\mathrm{SiN}_{x}$ :D film with $\mathrm{Xg}=0.95$ annealed at the temperature from 300 to $800{ }^{\circ} \mathrm{C}$ for $10 \mathrm{~min}$ in each step. (b) The variation of integrated IR peak intensities of $a-\mathrm{SiN}_{x}: \mathrm{D}(\boldsymbol{\bullet})$ and $a-\mathrm{SiN}_{x}: \mathrm{H}(\boldsymbol{\Delta})$ as a function of different annealing temperatures.

$\mathrm{Xg}=0.95$ were annealed to over $600^{\circ} \mathrm{C}$, a new peak at 1070 $\mathrm{cm}^{-1}$ emerges, which should be the transverse optical phonon band of $\mathrm{SiN}_{x}$ network. ${ }^{14}$ In Fig. 6(a), a small band at $1128 \mathrm{~cm}^{-1}$ emerges from the shoulder when $a-\operatorname{SiN}_{x}$ :D film with $\mathrm{Xg}=0.95$ is annealed, which is assigned to be the LO mode of the $\mathrm{Si}-\mathrm{N}$ stretching mode vibration. ${ }^{15,16}$ The $\mathrm{Si}-\mathrm{H}$ stretching mode vibration of $a-\mathrm{SiN}_{x}: \mathrm{H}$ film with $\mathrm{Xg}=0.5$ is at $2133 \mathrm{~cm}^{-1}$ which is slightly lower than the $a-\mathrm{SiN}_{x}: \mathrm{H}$ film with $\mathrm{Xg}=0.95\left(2150 \mathrm{~cm}^{-1}\right)$ resulting from the decrease of the nitrogen ratio. The peak at $1565 \mathrm{~cm}^{-1}$ in $a-\mathrm{SiN}_{x}$ :D film with $\mathrm{Xg}=0.5$ is the $\mathrm{Si}-\mathrm{D}$ stretching mode bonded to nitrogen atoms; the shoulder at $1523 \mathrm{~cm}^{-1}$ is assigned to be $\mathrm{Si}-\mathrm{D}$ or $\mathrm{Si}-\mathrm{D}_{2}$ located in a large void in the silicon nitride environment. ${ }^{7}$ In $a-\mathrm{SiN}_{x}: \mathrm{H}$ film with $\mathrm{Xg}=0.5$, the peak at $660 \mathrm{~cm}^{-1}$ is the $\mathrm{Si}-\mathrm{H}$ wagging mode vibration back bonded to nitrogen atoms. A peak of $a-\mathrm{SiN}_{x}: \mathrm{D}$ film with $\mathrm{Xg}=0.5$ is at $603 \mathrm{~cm}^{-1}$, which is attributed to the mixture of the $\mathrm{N}_{3} \mathrm{Si}-\mathrm{D}$ and $\mathrm{N}_{2} \mathrm{Si}-\mathrm{D}$ bending mode vibrations. The small peak at $704 \mathrm{~cm}^{-1}$ should be the $\mathrm{Si}-\mathrm{D}_{2}$ bending mode vibration in the $\mathrm{N}_{2} \mathrm{Si}-\mathrm{D}_{2}$ configuration. In the $a-\mathrm{SiN}_{x}$ :D film with $\mathrm{Xg}=0.5$, the weak peak at $527 \mathrm{~cm}^{-1}$ is related to the $\mathrm{Si}-\mathrm{D}$ rocking mode vibration in the plane defined by the $\mathrm{D}-\mathrm{Si}-\mathrm{N}$ unit. In $a-\mathrm{SiN}_{x}: \mathrm{H}$ film with $\mathrm{Xg}=0.5$, the small peak at $590 \mathrm{~cm}^{-1}$ might attribute to the carbon impurity in the substrate. ${ }^{17}$

A measure of the amount of microvoid is given by the ratio, $R=I_{3445} /\left(I_{3342}+I_{3445}\right)$. This is calculated to be $1.9 \%$ for the $a-\mathrm{SiN}_{x}: \mathrm{H}$ films with $\mathrm{Xg}=0.95$. By analogy, the microvoid fraction of the $a-\mathrm{SiN}_{x}$ :D films with $\mathrm{Xg}=0.95$, obtained from the modes at 2470 and $2562 \mathrm{~cm}^{-1}$, is $3.2 \%$. This means that there are more microvoids in the $a-\mathrm{SiN}_{x}: \mathrm{D}$ film. Therefore, the refractive index of the $a-\mathrm{SiN}_{x}: \mathrm{D}$ film is smaller than that of the $a-\mathrm{SiN}_{x}: \mathrm{H}$ film. Figure 6(b) shows the normalized integrated IR intensity of the $\mathrm{N}-\mathrm{D}$ stretching mode vibration in $a-\mathrm{SiN}_{x}$ :D film with $\mathrm{Xg}=0.95$ and $\mathrm{N}-\mathrm{H}$ stretching mode vibration in $a-\mathrm{SiN}_{x}: \mathrm{H}$ film with $\mathrm{Xg}=0.95$ versus the annealing temperature. The integrated intensity is normalized to original intensity prior to the thermal annealing. Although the growth rate of $a-\operatorname{SiN}_{x}: \mathrm{D}$ film with $\mathrm{Xg}$ $=0.95$ is lower than that of $a-\mathrm{SiN}_{x}: \mathrm{H}$ film with $\mathrm{Xg}=0.95$, the disappearance rate of $\mathrm{N}-\mathrm{D}$ bonds is more rapid than that of $\mathrm{N}-\mathrm{H}$ bonds. It also suggests that the $a-\mathrm{SiN}_{x}: \mathrm{H}$ film is denser than $a-\mathrm{SiN}_{x}$ :D film in the same growth condition although the growth rate of the $a-\mathrm{SiN}_{x}: \mathrm{D}$ film is slower, which is consistent with the difference in the refractive indexes.

Figures 7(a) and 7(b) display the IR spectra of silicon oxynitride films. In Fig. 7(a), the $\mathrm{SiH}_{n}$ bond stretching band in $a-\mathrm{SiO}_{x} \mathrm{~N}_{y}: \mathrm{H}$ film with $\mathrm{Xg}=0.6$, between 2300 and 2000 $\mathrm{cm}^{-1}$, shows three distinct peaks at 2245, 2195, and 2145 $\mathrm{cm}^{-1} .{ }^{18}$ The main peak of this vibration in the $a-\mathrm{SiO}_{x} \mathrm{~N}_{y}: \mathrm{H}$ film with $\mathrm{Xg}=0.15$ is $2095 \mathrm{~cm}^{-1}$, which corresponds to the $\mathrm{Si}-\mathrm{H}_{n}$ in a large void in the oxygen environment. In the $a-\mathrm{SiO}_{x} \mathrm{~N}_{y}: \mathrm{H}$ film with $\mathrm{Xg}=0.6$, the fractions of peaks at 2245 and $2195 \mathrm{~cm}^{-1}$ increase because the ratio of $\mathrm{N}_{2} \mathrm{O}$ increases. The $\mathrm{Si}-\mathrm{H}$ groups can be written as $\mathrm{HSiSi}_{3-n} \mathrm{O}_{n}$, with $n=0-3$, and the proposed frequencies are $2095+50 n$ $\mathrm{cm}^{-1}$. The greater electronegativity of oxygen compared to nitrogen draws charge away from the $\mathrm{Si}$ atom of $\mathrm{Si}-\mathrm{H}$ bond and causes the $\mathrm{Si}-\mathrm{H}$ stretching frequency to $2245 \mathrm{~cm}^{-1}$. In Fig. 7(b), for $a-\mathrm{SiO}_{x} \mathrm{~N}_{y}$ :D film with $\mathrm{Xg}=0.15$, a small peak at $1528 \mathrm{~cm}^{-1}$ would be the $\mathrm{Si}-\mathrm{D}$ or $\mathrm{Si}-\mathrm{D}_{2}$ in large void in the oxygen environment. With the similar concept as hydrogenated silicon oxynitride, as shown in Figs. 7(a) and 7(b), the $\mathrm{Si}-\mathrm{D}$ groups can be written as $\mathrm{DSiSi}_{3-n} \mathrm{O}_{n}$, with $n$ $=0-3$, and the proposed frequencies are $1528+34 \mathrm{ncm}^{-1}$. 


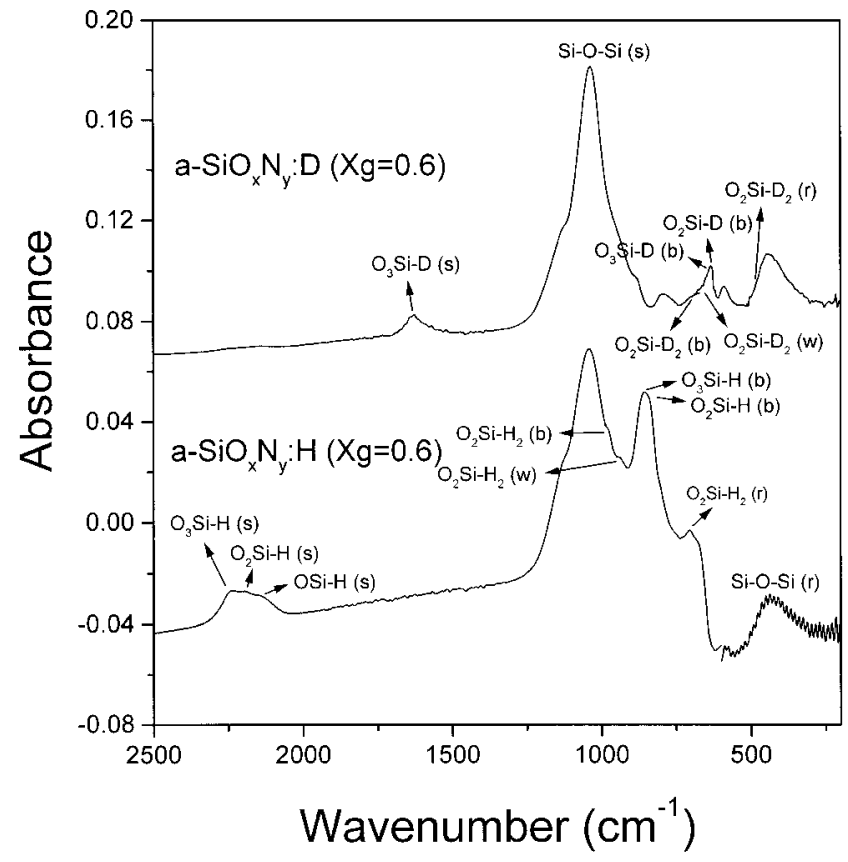

(a)

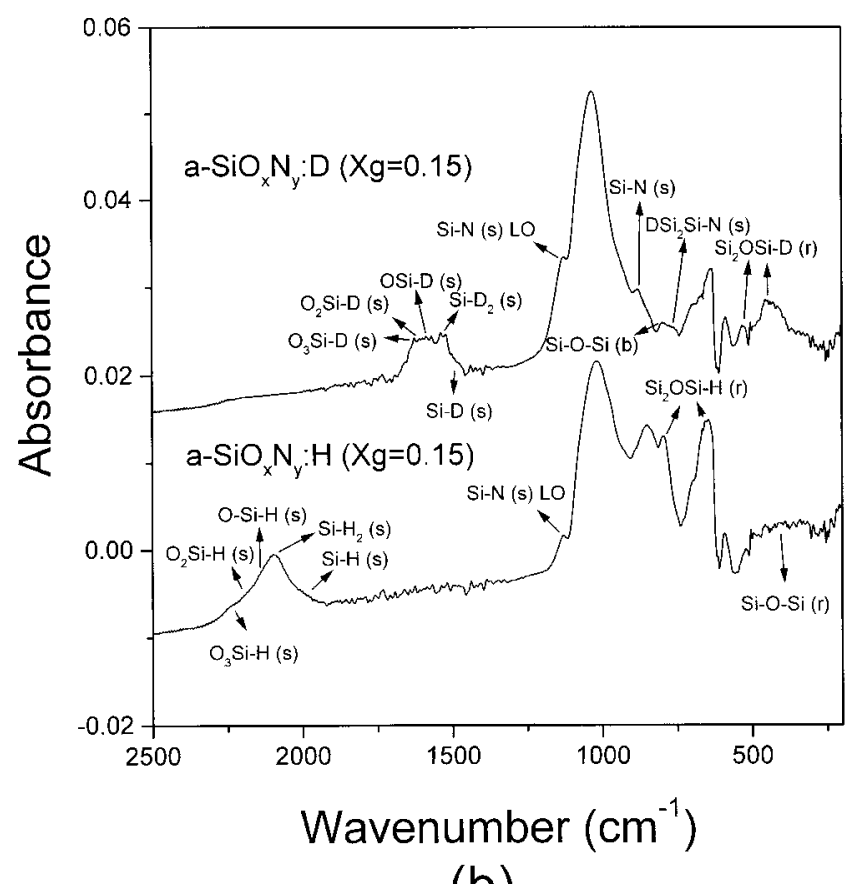

(b)

FIG. 7. IR spectra of $a-\mathrm{SiO}_{x} \mathrm{~N}_{y}: \mathrm{D}$ and $a-\mathrm{SiO}_{x} \mathrm{~N}_{y}: \mathrm{H}$ with (a) $\mathrm{Xg}=0.6$, (b) $\mathrm{Xg}=0.15$. The upper curve is the IR spectra of $a-\mathrm{SiO}_{x} \mathrm{~N}_{y}: \mathrm{D}$ and the lower curve is the IR spectra of $a-\mathrm{SiO}_{x} \mathrm{~N}_{y}: \mathrm{H}$.

The concentrations of $\mathrm{Si}-\mathrm{D}$ and $\mathrm{Si}-\mathrm{H}$ bonds of the $a-\mathrm{SiO}_{x} \mathrm{~N}_{y}: \mathrm{D}$ and $\mathrm{SiO}_{x} \mathrm{~N}_{y}: \mathrm{H}$ film with $\mathrm{Xg}=0.6$ are listed in Table II, calculated by Eq. (4). The Si-D stretching mode of $a-\mathrm{SiO}_{x} \mathrm{~N}_{y}$ :D film with $\mathrm{Xg}=0.6$ was almost at $1630 \mathrm{~cm}^{-1}$, in the configuration of $\mathrm{O}_{3} \mathrm{Si}-\mathrm{D}$, and the concentration of $\mathrm{Si}-\mathrm{D}$ is smaller than that of $\mathrm{Si}-\mathrm{H}$. Therefore, the fraction of oxygen atoms of $a-\mathrm{SiO}_{x} \mathrm{~N}_{y}: \mathrm{D}$ film with $\mathrm{Xg}=0.6$ should be larger than that of $a-\mathrm{SiO}_{x} \mathrm{~N}_{y}: \mathrm{H}$ film with $\mathrm{Xg}=0.6$, and thus the band gap of $a-\mathrm{SiO}_{x} \mathrm{~N}_{y}: \mathrm{D}$ film with $\mathrm{Xg}=0.6$ is larger than $a-\mathrm{SiO}_{x} \mathrm{~N}_{y}: \mathrm{H}$ film with $\mathrm{Xg}=0.6$, which is consistent with the PL and transmission spectra. The stretching mode of $\mathrm{Si}-\mathrm{O}-\mathrm{Si}$ bond of $a-\mathrm{SiO}_{x} \mathrm{~N}_{y}: \mathrm{D}$ and $\mathrm{SiO}_{x} \mathrm{~N}_{y}: \mathrm{H}$ films with $\mathrm{Xg}=0.6$ and 0.15 are at $1036,1041,1031$, and $1016 \mathrm{~cm}^{-1}$, respectively. In the $a-\mathrm{SiO}_{x} \mathrm{~N}_{y}: \mathrm{D}$ and $\mathrm{SiO}_{x} \mathrm{~N}_{y}: \mathrm{H}$ film with $\mathrm{Xg}=0.15$, a small band at $1128 \mathrm{~cm}^{-1}$ which is small and like a shoulder in $a-\mathrm{SiO}_{x} \mathrm{~N}_{y}: \mathrm{D}$ and $\mathrm{SiO}_{x} \mathrm{~N}_{y}: \mathrm{H}$ films with $\mathrm{Xg}$ $=0.6$ is assigned to be the LO mode of the $\mathrm{Si}-\mathrm{N}$ stretching mode vibration rather than the $\mathrm{LO}$ mode of the $\mathrm{Si}-\mathrm{O}-\mathrm{Si}$ stretching mode vibration. This peak is the stretching mode of $\mathrm{Si}-\mathrm{N}$ and the weak band at $774 \mathrm{~cm}^{-1}$ is suggested to be the $\mathrm{Si}-\mathrm{N}$ stretching mode in $\mathrm{DSi}_{2}-\mathrm{Si}-\mathrm{N}$ configuration, which is comparatively lower than the $\mathrm{Si}-\mathrm{N}$ stretching mode in $\mathrm{H}-\mathrm{Si}_{2}-\mathrm{Si}-\mathrm{N}$ configuration by $6 \mathrm{~cm}^{-1}$ due to the difference in the mass. ${ }^{14}$ The peak at $798 \mathrm{~cm}^{-1}$ is the $\mathrm{Si}-\mathrm{O}-\mathrm{Si}$ bending mode vibration. ${ }^{17}$ In Fig. 7(a), the shoulders of $a-\mathrm{SiO}_{x} \mathrm{~N}_{y}: \mathrm{H}$ film with $\mathrm{Xg}=0.6$ at 978 and $938 \mathrm{~cm}^{-1}$ are the $\mathrm{Si}-\mathrm{H}$ bending and wagging mode vibration in the configuration of $\mathrm{H}_{2}-\mathrm{Si}-\mathrm{O}_{2} \cdot{ }^{14}$ In the hydrogenated silicon oxynitride films with $\mathrm{Xg}=0.6$ and 0.15 , the small peak at $704 \mathrm{~cm}^{-1}$ is the rocking mode of the $\mathrm{O}_{2} \mathrm{Si}-\mathrm{H}_{2}$ configuration. ${ }^{18}$ By multiplying the shoulders of the deuterated silicon oxynitride films with $\mathrm{Xg}=0.6$ and 0.15 at 700,673 , and $490 \mathrm{~cm}^{-1}$ by $\sqrt{2}$, they correspond to 989,951 , and $693 \mathrm{~cm}^{-1}$, which are close to the $\mathrm{Si}-\mathrm{H}$ bending, wagging, and rocking mode vibration in the configuration of $\mathrm{H}_{2}-\mathrm{Si}-\mathrm{O}_{2}$, respectively. Therefore, the peaks at 700,673 , and $490 \mathrm{~cm}^{-1}$ are the $\mathrm{Si}-\mathrm{D}$ bending, wagging, and rocking mode vibration in the configuration of $\mathrm{D}_{2}-\mathrm{Si}-\mathrm{O}_{2}$, respectively. In the hydrogenated silicon oxynitride films with $\mathrm{Xg}=0.6$ and 0.15 , the peak at $855 \mathrm{~cm}^{-1}$ is assigned to be the $\mathrm{Si}-\mathrm{H}$ bending modes with $\mathrm{HSi}-\mathrm{O}_{3}$ and the $\mathrm{HSi}-\mathrm{O}_{2}$ configurations. ${ }^{19,20}$ Since the two vibration frequencies are very close, the two modes may overlap. Corresponding to these two peaks, the $634 \mathrm{~cm}^{-1}$ bands of the deuterated silicon oxynitride films with $\mathrm{Xg}=0.6$ and 0.15 are proposed to be the $\mathrm{Si}-\mathrm{D}$ bending modes vibration with $\mathrm{DSi}-\mathrm{O}_{3}$ and the $\mathrm{DSi}-\mathrm{O}_{2}$ configurations. In $a-\mathrm{SiO}_{x} \mathrm{~N}_{y}: \mathrm{H}$ with $\mathrm{Xg}=0.15$, the $\mathrm{Si}-\mathrm{H}$ rocking mode vibrations at 796 and $645 \mathrm{~cm}^{-1}$ occur when the $\mathrm{Si}-\mathrm{H}$ group has one nearest $\mathrm{O}$-atom neighbor, that is, the $\mathrm{HSi}-\mathrm{OSi}_{2}$ configuration. ${ }^{13}$ The $796 \mathrm{~cm}^{-1}$ band is related to the $\mathrm{Si}-\mathrm{H}$ rocking mode vibration in the plane defined by the $\mathrm{H}-\mathrm{Si}-\mathrm{O}$ unit. This vibration couples with the $\mathrm{Si}-\mathrm{O}-\mathrm{Si}$ bending mode vibration. ${ }^{20}$ The $645 \mathrm{~cm}^{-1}$ band is associated with $\mathrm{Si}-\mathrm{H}$ rocking mode vibration perpendicular to the plane defined by the $\mathrm{H}-\mathrm{Si}-\mathrm{O}$ unit. ${ }^{21}$ The $430 \mathrm{~cm}^{-1}$ band of $a-\mathrm{SiO}_{x} \mathrm{~N}_{y}: \mathrm{H}$ with $\mathrm{Xg}=0.6$ is the rocking mode vibration of $\mathrm{Si}-\mathrm{O}-\mathrm{Si}$. This peak of $a-\mathrm{SiO}_{x} \mathrm{~N}_{y}: \mathrm{D}$ with $\mathrm{Xg}=0.6$ is at $440 \mathrm{~cm}^{-1}$, which is a little higher than $a-\operatorname{SiN}_{x}: \mathrm{H}$ with $\mathrm{Xg}=0.5$. When the IR spectra of the silicon oxynitride films with $\mathrm{Xg}=0.15$ in Fig. 7(b) are compared, the peak of $a-\mathrm{SiO}_{x} \mathrm{~N}_{y}: \mathrm{D}$ with $\mathrm{Xg}=0.15$ at $440 \mathrm{~cm}^{-1}$ protrudes from the $\mathrm{Si}-\mathrm{O}-\mathrm{Si}$ rocking mode band. This is the $\mathrm{Si}-\mathrm{D}$ rocking mode vibration when the $\mathrm{Si}-\mathrm{D}$ group has one nearest $\mathrm{O}$-atom neighbor, i.e., the $\mathrm{DSi}-\mathrm{OSi}_{2}$ configuration. The $532 \mathrm{~cm}^{-1}$ band is related to the $\mathrm{Si}-\mathrm{D}$ rocking mode vibration in the plane defined by the $\mathrm{D}-\mathrm{Si}-\mathrm{O}$ unit. The $440 \mathrm{~cm}^{-1}$ band is associated with $\mathrm{Si}-\mathrm{D}$ rocking mode vibration perpendicular to the plane defined by 
the $\mathrm{D}-\mathrm{Si}-\mathrm{O}$ unit, which couples with $\mathrm{Si}-\mathrm{O}-\mathrm{Si}$ rocking mode vibration.

\section{CONCLUSION}

Hydrogenated and deuterated silicon nitride $\left(a-\mathrm{SiN}_{x}: \mathrm{H}\right.$ and $\left.a-\mathrm{SiN}_{x}: \mathrm{D}\right)$ and silicon oxynitride $\left(a-\mathrm{SiO}_{x} \mathrm{~N}_{y}: \mathrm{H}\right.$ and $\left.a-\mathrm{SiO}_{x} \mathrm{~N}_{y}: \mathrm{D}\right)$ films were studied in detail. The IR spectra of $a-\mathrm{SiN}_{x}: \mathrm{H}, a-\mathrm{SiN}_{x}: \mathrm{D}, a-\mathrm{SiO}_{x} \mathrm{~N}_{y}: \mathrm{H}$, and $a-\mathrm{SiO}_{x} \mathrm{~N}_{y}: \mathrm{D}$ are identified and compared. On one hand, the refractive indexes of the deuterated materials are lower than those of the hydrogenated materials in the same growth condition, and on the other hand, the optical gaps and PL peaks of the deuterated materials are higher than those of the hydrogenated materials. Besides, it is observed that the $a-\mathrm{SiN}_{x}: \mathrm{H}$ film is denser than $a-\mathrm{SiN}_{x}: \mathrm{D}$ film, and the growth rate of $a-\mathrm{SiO}_{x} \mathrm{~N}_{y}: \mathrm{D}$ is higher than $a-\mathrm{SiO}_{x} \mathrm{~N}_{y}: \mathrm{H}$ in the same growth condition. From the IR spectra, the interaction between the $\mathrm{N}-\mathrm{D}$ bond rocking vibration and $\mathrm{Si}-\mathrm{N}$ bond stretching vibration is observed. This interaction pushes the $\mathrm{N}-\mathrm{D}$ bond rocking vibration to a higher energy.

\section{ACKNOWLEDGMENT}

This work is supported by National Science Council of the Republic of China under Contract No. NSC 90-2215-E002-002.
${ }^{1}$ J. W Lyding, K. Hess, and I. C. Kiziyalli, Appl. Phys. Lett. 68, 2526 (1996).

${ }^{2}$ G. Ganguly, A. Suzuki, S. Yamasaki, K. Nomoto, and A. Matsuda, J. Appl. Phys. 68, 3738 (1990).

${ }^{3}$ W. A. Nevin, H. Yamagushi, K. Asaoka, H. Nishio, and Y. Tawada, Appl. Phys. Lett. 59, 3294 (1991).

${ }^{4}$ C. G. Van de Walle and W. B. Jackson, Appl. Phys. Lett. 69, 2441 (1996).

${ }^{5}$ J. H. Wei, M. S. Sun, and S. C. Lee, Appl. Phys. Lett. 71, 1498 (1997).

${ }^{6}$ J. H. Wei and S. C. Lee, J. Appl. Phys. 85, 543 (1999).

${ }^{7}$ A. Shih, J. L. Yeh, S. C. Lee, and T. R. Yang, J. Appl. Phys. 88, 1684 (2000).

${ }^{8}$ J. Tauc, Amorphous and Liquid Semiconductors (Plenum, London, 1974), Chap. 4.

${ }^{9}$ M. H. Brodsky, Solid State Commun. 36, 55 (1980).

${ }^{10}$ D. V. Tsu, G. Lucovsky, and M. J. Mantini, Phys. Rev. B 33, 7069 (1986).

${ }^{11}$ S. Hasegawa, H. Anbutsu, and Y. Kurata, Philos. Mag. B 59, 365 (1989).

${ }^{12}$ G. Lucovsky, Solid State Commun. 29, 571 (1979).

${ }^{13}$ M. H. Brodsky, M. Cardona, and J. J. Cuomo, Phys. Rev. B 16, 3556 (1977).

${ }^{14}$ K. C. Lin and S. C. Lee, J. Appl. Phys. 72, 5474 (1992).

${ }^{15}$ M. Weider, A. Roseler, and M. Eichler, Thin Solid Films 234, 337 (1993).

${ }^{16}$ M. Firon, C. Bonnelle, and A. Mayeux, J. Vac. Sci. Technol. A 14, 2488 (1996).

${ }^{17}$ I. W. Boyd and J. I. B. Walson, J. Appl. Phys. 53, 4166 (1982).

${ }^{18}$ J. L. Yeh and S. C. Lee, J. Appl. Phys. 79, 656 (1996).

${ }^{19}$ J. C. Knight, R. A. Street, and G. Lucovsky, J. Non-Cryst. Solids 35-36, 279 (1980).

${ }^{20}$ G. Lucovsky, Sol. Energy Mater. 8, 165 (1982).

${ }^{21}$ G. Lucovsky, J. Yang, S. S. Chao, J. E. Tyler, and J. I. B. Wilson, Phys. Rev. B 28, 3225 (1983). 